important results are being obtained in the crystal chemistry of vanadium minerals and the stereochemistry and absolute configuration are being established for certain narcotics the structural formula of which have long been in dispute.

The Division of Mechanical Engineering records increasing emphasis on longer term investigations in thermodynanics and engine evolution, and many new propulsion problems in air transport are also being studied, especially those arising from vertical takeoff and landing, while certain fluid mechanical aspects of nuclear reactors are being examined. At the National Aeronautical Establishment a substantial research effort has been redirected to problems of high-speed and very high-speed flight, and in particular an increasing effort is being applied to problems arising from very high temperatures. Much of the work of the Radio and Electrical Engineering Division was concerned with defence projects, but the remainder of the programme was concerned with fundamental problems in electrical engineering and electronics, and a pressure gauge capable of measuring the atmospheric pressure at satellite altitudes was developed.

Work at the Prairie Regional Laboratory, Saska. toon, is devoted to a more thorough understanding of the plants and micro-organisms growing on the prairies; but to promote the development of oil-seed crops as alternatives to cereal crops an intensive study of the chemical structure of glycerides was undertaken. At the Atlantic Regional Laboratory, Halifax, where the most efficient way of drying the commercially important plant materials of the region has been studied, a semi-commercial scale batch dryer was developed and a continuous dryer is now being designed and constructed in co-operation with industry.

\title{
SAFETY OF YOUNG PEOPLE IN FACTORIES
}

$\mathrm{P}^{\mathrm{n}}$ ROBABLY the most important chapter in the annual report of the Chief Inspector of Factories for 1959* is one of two chapters dealing with subjects of interest without being necessarily restricted to the events of the year-that dealing with the prevention of accidents to young persons. While the consistent downward trend in the number of fatal accidents continued in 1959, there was an increase in the number of reported accidents, and the Chief Inspector is disturbed at the increase in the number of accidents to young persons, from 9,838 in 1958 to 11,001 in 1959. This rise is not due just to an increase in the numbers employed, and indicates clearly that redoubled efforts will be necessary to hold the rate of accidents to young people in check, as increasing numbers of school-leavers enter industry in the coming years. The present drive to train young persons in safe working must be intensified, he writes, not only by industry but also by secondary and technical sehools and colleges.

The Chief Inspector, in his letter of presentation, points out that it is evident from the large number of accidents to the head and neck, to the feet and ankles and to the hands, that much more could be done to reduce such accidents by the wearing of suitable clothing, such as safety helmets, goggles, adequate footwear and gloves, and that careful attention would reduce dramatically the grand total of all reported industrial accidents. Young persons, particularly during the first year of employment, tend not to take adequate safety precautions and are more liable to run the risk of suffering injury than older workers. Ignorance of factory conditions and hazards, inexperience and natural curiosity, the desire to prove oneself, contempt for 'safety first' principles, liability to fatigue, and boredom leading to 'skylarking', can all be contributory factors, and there are many examples in the resorc's of the factory inspectorate of the kind of accident in which young. sters are concerned for such reasons.

Young persons, it is clear, enter employment with a handicap, and it is the responsibility of their employers to help them overcome it by providing * Ministry of Labour. Annual Report of the Chief Inspector of
Factories on Industrial Health, 1959. Pp. iii +60. (Cmnd. 1137.) (London : H.M. Stationery Office.) 3s. 6d. net. sound training and careful supervision and by insisting on high standards of obedience to safety rules. Many of the large firms have, in fact, built up excellent organizations for this purpose, and in his annual report for 1951 the Chief Inspector, Sir George Barnett, attributed the considerable reduction in the post-war accident-rate mainly to this factor. Many managements, however, did not trouble to make allowances, and since then the rate of decrease of accidents to young persons has slowed down, and the decrease in the number of accidents to young persons is, moreover, proportionately less than the corresponding decrease for all employed persons.

While there have been several important pieces of legislation since 1937 affecting young persons employed in factories, such as prohibition or restriction of employment in certain dangerous or unhealthy trades, prohibition of employment on certain types of dangerous machinery or in carrying or lifting excessive weights, limitation of the number of hours a young person may work and the provision of medical supervision, the legal contribution must be supplemented by effective training and supervision, beginning in schools and colleges and continuing in industry. There are few places where the young can be prepared for work in the factory so well as in secondary school and college workshops and housecraft rooms. Classes there provide an excellent opportunity for showing how tools should be main. tained and used, and machines properly guarded. The teacher, too, can inculcate a degree of safety consciousness and an acceptance of discipline in the correct use of machines and tools which is invaluable in factory life. As the Chief Inspector observed in addressing a conference on "Accident Prevention in Technical Colleges" at Blackpool in June 1958, arranged by the North West Regional Advisory Council for Further Education, his teachers are the best people to give the neophyte entering the factory the confidence that he requires.

The Chief Inspector did not suggest that safety should be taught as a subject per se, but rather that safety teaching should go hand in hand with the various subjects, and in the present report the Chief 
Inspector refers to encouraging developments as a result of the initiative of the North West Regional Council. The Council itself set up an Industrial Hazards Sub-committee, which organized three courses in accident prevention at Liverpool, Manchester and Preston, and afterwards the Cheshire County Education Authority established a permanent committee to deal with safety training in colleges in Cheshire, on which both industry and college staffs are represented. The general problem has also been discussed at a conference held recently in Glasgow, attended by a number of principals, heads of departments and teachers from technical colleges in Scotland, and addressed by senior members of the factory inspectorate.

Among the suggestions which found favour with the conference were publication of a safety code for each college; appointment of a member of the teaching staff to be specially responsible for safety matters ; inclusion in examination papers of questions relating to safety; and close liaison between the technical colleges and inspectors of factories, who can give occasional lectures and advise on safety precautions. A pamphlet, comprising mainly speeches delivered at the Blackpool conference, has already been distributed to technical college teachers in the north-west region and received a wide circulation in other parts of Britain, but these efforts are only a beginning and, as the Chief Inspector now emphasizes, much more remains to be done if young people are to come into industry adequately prepared and the transition from school to industry is to be as smooth as possible. $\mathrm{He}$ urges that it is important for the success of this work that education authorities and individual principals and heads of departments at technical colleges should recognize the seriousness of the problem and the need to take steps to deal with it.

It might be added that this is a matter that could well be recognized as a professional responsibility by scientists and technologists, not simply when their own work as teachers or in industry brings them in direct contact with it, but through their professional organizations. Their co-operation and guidance can sometimes make the decisive difference between success and failure, and this is no less true in respect of some of the suggestions for action by employers which are made in this special chapter of the Chief Inspector's report. Apart from care in picking young people for the work they are going to do, training schemes should include six particular points. The young worker should be taken around those parts of the factory where he will work and should be shown what the principal dangers are, how they arise and how to avoid them. A fully competent adult worker should directly supervise the young person's work during the initial period of training and the proper method of working any machine on which the youngster is to be employed should be illustrated in detail and the dangers associated with other undesirable methods explained. Departmental managers and other supervisory grades should be given clear instructions on accident prevention and on the need for keeping close control over the work of the young persons under their charge, and strict discipline should be enforced in the adoption of safe methods. Special safety propaganda should hammer home the important points and make young workers aware of the importance which is attached by the employer, and all in supervisory positions, to the principles of accident prevention.

Clearly not all these points concern either the scientist or technologist as such, but in many of them his interest and co-operation can be decisive factors. Moreover, as the report concludes, it is not only firms with large numbers of youngsters and great financial resources that can achicve substantial results. It is well within the capacity of managers and supervisory staffs in smaller firms to make the effort to see that their young recruits have a good and safe start in their chosen career, and many such managers and members of supervisory staffs, as well as teachers and departmental heads in technical colleges, are them. selves likely to possess scientific or technological qualifications.

\section{THE COMMONWEALTH SCIENTIFIC AND INDUSTRIAL RESEARCH ORGANIZATION IN AUSTRALIA}

T HE eleventh annual report of the Commonwealth Scientific and Industrial Research Organization in Australia, covering the year 1958-59*, notes a number of changes in organization.

The Division of Industrial Chemistry has become the Chemical Research Laboratories, with three Divisions, Chemical Physies, Mineral Chemistry and Physical Chemistry, and three independent Sections, namely, Cement and Ceramics, Chemical Engineering and Organic Chemistry. Similarly, the Wool Textile Research Laboratories have been renamed the Wool Research Laboratories, with Divisions of Protein Chemistry, Textile Physics and Textile Industry. The Soil Mechanics Section of the Division of Soils has become an independent section of the Organization and the unit of the Division of Plant Industry and Plant and Soil Laboratory, Brisbane, becomes an independent Division of Tropical Pastures, while the

* Eleventh Annual Report of the Commonwealth Scientific and Industrial Research Organization for year 1958-59. Pp. 181. (Can-
berra: Commonwealth Government Printer, 1960.) former Radio Research Board Laboratory, Camden, New South Wales, has become an independent Upper Atmosphere Section. Collaboration with the universities has been further extended by the establishment with the University of Melbourne of a joint laboratory for research and soil mechanics at Syndal, Victoria, and of a Meat Research and Teaching Centre at the University of Sydney Animal Husbandry Farms, Camden, New South Wales. A Rice Research Station is being established on the coastal plains near Darwin, where studies will bo made of nutrition and water requirements of rice and of possibilities for developing varieties well adapted to that environment. Two frigates, specially equipped for oceanographic survey work, are being made available to the Organization for periods of about 12 weeks a year, and this assistance will facilitate the more comprehensive and regular programme of observations which must be undertaken before a clear picture of the oceanography of the waters surrounding Australia can be developed. 